\title{
Introduction: the issues at stake
}

\section{Noemi Levy-Orlik, Jorge Alonso Bustamante-Torres and Louis-Philippe Rochon}

The dominant capitalist structures of the last third of the 20th century have been noteworthy for globalising and internationalising the social relationships of production, whose highest expression has been the cross-border movement of capital, which peaked in the 1990s (Levy-Orlik and Bustamante-Torres, Chapter 6 in this book). The political and economic agenda behind this model is dominated by Developed Countries (DCs), through a triad formed by their governments, banks and non-bank financial conglomerates, and non-financial conglomerates. Together, this triad maximises the gains of big capital through financial innovations supported by complex financial relations and global value chains (GVCs), which keep financial activities in the DCs and minimise production costs by sourcing production in Emerging and Developing Countries (EDeCs). The Global Financial Crisis (GFC) which exploded in 2008 weakened but did not break this economic and social order, with an uneven response in DCs and EDeCs (Painceira and Saludjian, Chapter 11 in this book), as the former embraced nationalist policies to curtail globalisation of their corporations while the latter doubled down on globalisation and internationalisation, further opening their economies and deepening their reliance on GVCs.

Financial deregulation and globalisation have deep roots in economic theory. The dominant theory legitimises capital mobility because it assumes that it homogenises productivity and expands the benefits of economic growth and prosperity. From this perspective, it has been observed, on the one hand, that capital movements are driven by surplus savings and shrinking profit margins in DCs, as their economies reach a stationary level of economic growth and development in processes of capital accumulation (Solow, 1963; Dowrick and Rogers, 2002), finding new opportunities to maximise profits in EDeCs. Thus, exporting capital from developed to less developed regions boosts its profitability because the latter have insufficient savings, and - given the scarcity of capital - profitability is high. In this context, unrestricted mobility of financial and productive capital seeks to homogenise levels of productivity on a global level, making it a mechanism which equalises economic growth between developing and developed regions. On the other hand, from the perspective of EDeCs, a lack of savings limits their economic growth, and in addition government intervention in the form of interest rate reductions and credit mobilisation towards priority productive sectors causes financial repression, which in turn reinforces economic stagnation (including investment spending) and productive heterogeneity (McKinnon, 1973). In this context, capital mobility is a driver of development for emerging economies, especially in the dynamic sectors of the productive process, and the hegemony transnational companies exercise in the most dynamic sectors (e.g. export industry) is justified on the grounds that it transfers technology with productive spillovers while boosting competitiveness, employment, and wages. 
In this approach, the key to economic development is the diminishing marginal productivity of capital as the factor which determines return on investment and, given the equilibrium interest rate, establishes the volume of savings, and when savings and investment are equal capital returns are cancelled out. Therefore, free capital movement is essential to increasing savings in $\mathrm{EDeCs}$, which fuels economic growth and development in those regions. This approach rejects the theories of underdevelopment based on structural inequalities.

The heterodox school of thought has opposite views. Finance triggers growth, including investment, and raises savings (as a result of higher income). In dominant oligopolistic structures (Kalecki, 1971; Steindl, 1952), finance is derived from companies' profits from previous periods (internal funds), and rentier capital - accumulated by the capitalist class - which doesn't return to the productive sector through capitalist spending in the same periods, creating business cycles.

In other words, financial capital produces economic cycles, with expansionary phases explained by financial inflation and high debt volumes, followed by contractive periods of slower economic growth, which in turn can cause economic stagnation. Thus, external capital flows do not necessarily have a positive impact on economic growth or expand finance, nor do they homogenise growth and productivity.

An overview of social relationships of production in the capitalist system in the last third of the 20th century shows that the predictions made by mainstream economic thought were not fulfilled, and on the contrary financial instability increased. Since the breakdown of the post-war financial system, complex financial relationships have gained in importance through cross-border capital movements (between developed and developing regions and within each region) with the novelty of EDeCs taking part in capital exports. In this context, medium-size multinational enterprises (MNEs) were created in emerging economies (see UNCTAD, n.d.), which, while extending their reach to all capitalist regions, did not increase competition, but rather accentuated structural imbalances within EDeCs and between developed and emerging regions.

The economic model that emerged from globalisation and internationalisation shifted manufacturing production to EDeCs (Lazonick and O'Sullivan, 2000) through GVCs (Aguiar de Medeiros and Trebat, 2018) and financial multinationals spread to all capitalist economies, without reducing inequalities. Latin America failed to become more competitive and the countries' external current account continued under structurally entrenched deficits, without achieving financial depth (in the stock and bond markets). This process had several repercussions.

First, productive costs shrank, especially those related to the workforce (Bellofiore et al., 2010), tax payments contracted, and clean technologies were delayed in EDeC production process, especially in Latin America. As a result, these economies' comparative advantages rested on low production costs and exploitation of natural resources, the control of which was transferred to international corporations, allowing them to extract maximum profit from developing economies.

Second, financial institutions were strengthened by the privatisation of social services (pensions, healthcare, education, etc.) that were commercialised in the form of insurance (medical, educational, pension funds, etc.) by institutional funds that channelled their financial flows to the leading international centres. This in turn spurred worldwide financial inflation, with massive financial gains, involving all economic agents (financial and non-financial corpora- 
tions, government, and families). The singularity of this process is that the EDeCs were unable to develop or expand their own financial centres, bolstering international centres (Wall Street and the City in London), on the one hand, while reducing the scope of action for EDeCs. In this scenario, the goal of MNEs from EDeCs headquartered in developed countries is to gain access to more abundant, lower-cost liquidity from such financial centres.

Third, international financial flows were modified. On the one hand, their composition changed as foreign investment (portfolio and direct investment) took the lead, displacing international loans with the aid of financial innovation. On the other hand, the volume of capital movement increased sixfold, without increasing total savings in EDeCs - the substitution effect of foreign savings dominated over domestic savings - or financing. The most relevant effect of the internationalisation of financial systems is that EDeCs gained access to international capital through conversion of private instruments denominated in local currency into international units of account, creating a new form of international monetary asymmetry. ${ }^{1}$ EDeCs, especially in Latin America and particularly in Mexico, succumbed to the illusion of unlimited access to international liquidity in exchange for almost complete opening of their financial systems, without deepening of their own financial markets. In fact, savings were separated from finance, the former being a product of production, restricted to domestic spaces, while the latter is provided by international agents (Borio and Disyatat, 2015). This process produced increased financial instability, because capital inflows depend on perceptions of EDeCs' economic performance among institutional investors and large international consortia. EDeCs were obliged to raise their interest rates and overvalue their currencies to attract foreign capital, which explains the excess liquidity that followed the 2008 GFC (due to FED quantitative easing) and the subsequent economic recession, starting in 2014 when the US attempted to normalise its monetary policy.

Fourth, the deregulation, globalisation, and internationalisation of productive processes imposed an export-based model, which debilitated domestic markets, due to the separation of supply and demand. Latin America took part in this productive process with severe disadvantages. Its appeal lay in its ability to supply raw materials and inexpensive labour. As a result, the productive process was not directed by a sector which produced investment goods (sector I in Marxist terms) and economies underwent a process of re-primarisation and labour organisation dominated by international contract manufacture or maquila.

The crises of the global and transnational production model were quick to appear, starting in EDeCs, linked to foreign capital movement and increased indebtedness, with strong contagious effects. The Mexican crisis (1994) topped the list of neoliberal crises sending powerful shockwaves throughout Latin America (Tequila Effect). DCs took longer to feel the effects of the globalised, financialised model, when the GFC struck the USA almost three decades later. Starting in 2007, financial movements in capital markets grew sluggish, triggering sharp financial deflation in October of the following year, followed by widespread MNE bankruptcies and the economic crash. The crisis also produced powerful shockwaves in Europe, due to the close financial ties between corporations on both sides of the Atlantic.

The DCs countered the 2008 GFC by implementing massive stimulus programs in 2009 (which they stopped in 2010), increased liquidity (quantitative easing) and diminished drastically the rate of interest, effectively halting bankruptcies and restarting economic activity, including financial trading. However, their economic recovery was slow and limited in scope (largely because the stimulus programs lasted only one year), with high unemployment 
because the terms of securitisation remained unchanged and the dominance of financial capital was maintained, with high levels of income concentration and poverty and growing volumes of debt to maintain consumption.

Once again, we find two answers for the crisis. Developed economies sought to restore "normalcy" by embracing nationalist policies, which have given way to a trade war between declining and emerging powers, hindering the recovery and continuity of the globalised export-based model and GVCs. Donald Trump came to power in the USA with the slogan "America First" and an unfulfilled promise to force transnationals to move their affiliates back to the US and reactivate employment, while the Brexit movement forced the UK to withdraw from the European Union (EU).

Considering the above arguments, the objective of this book is to discuss the dynamics of capital movements and the operations of corporations and, altogether, their effects on the productive and financial development of developing and emerging economies, particularly in Latin America. This book is divided into three sections and 14 chapters.

The first section deals with the Post-Crisis Capital Movement Trend and contains six chapters. Its purpose is to show that capital development has different effect in developed and developing and emerging economies countries. The first chapter, "Financial geography and the 'social reality of finance': Aspatial or 'real space' analyses of financial crises?" by Gary Dymski and Nicole Cerpa-Vielma, discusses globalisation from a heterodox perspective, not only considering time (following Post-Keynesians) but also space. The authors adopt an interdisciplinary framework between economy and geography and introduce the concept of "social reality of finance", illustrating their argument by exploring several economic models of financial crises in developing countries.

In the second chapter, written by Jan Toporowski, "The transmission mechanism of financial crisis to developing countries: why the 'global financial crisis' wasn't global', the author identifies three channels through which financial crises have been channelled to developing countries and emerging markets. The financial channel through illiquidity in the international monetary system that causes debt crises; the monetary channel, when exchange rates modify the value of external liabilities; and the export channel, when the value of exports falls below the value required to maintain production and service external debt. The developments of these channels, along with unconventional measures of monetary policy ensured that the 2008 financial crisis had only minimal effects in developing countries and emerging markets and concludes that capital controls are not an effective solution.

The next chapter, "Foreign direct investment, inequality, and macroeconomic stability on the eve of the COVID-19 crisis", by Hanna Szymborska, examines the relationship between foreign direct investment and income inequality. It focuses on the period following the Great Recession and seeks to understand the role of changing institutional setups in the global financial sector and the world economy after the 2007 crisis. The author analyses developed and developing countries, investigating trends in income inequality, balance of payments, and the outflows and inflows of FDI over time. The main findings are that the relationship between FDI and income inequality since 2008 is complex and the preliminary analysis of the available data does not reveal any systematic patterns between the different measures of income inequality and changes in FDI.

Jennifer Churchill, Bruno Bonizzi and Annina Kaltenbrunner, in Chapter 4, discuss "Pension funds and domestic debt markets in emerging economies." These authors review 
the relationship between foreign and domestic pension funds in domestic financial markets of emerging economies, arguing that given their longer-time horizon, pension funds are expected to contribute positively to the development of large and deep domestic local currency bond markets, and hence ease fiscal and external constraints in these countries. However, this does not necessarily apply due to the hierarchic and structured international financial and monetary systems that are linked to external vulnerability and financial market instability.

In Chapter 5, Mimoza Shabani discusses "The distribution of dividends of multinational banks operating in Latin America"; here she analyses the distribution of dividends in multinational banks that operate in Argentina, Brazil, Chile, Colombia, Mexico and Peru, on the basis of bank level data, for the period 2013-2019. The findings suggest that Mexico and Peru have the highest foreign bank participation in their banking sector. However, foreign banks in Brazil, Chile and Mexico have made higher dividend payments to the shareholders of their parent banks. This also holds when looking at dividend payments in relation to their earnings. This suggests that a large share of earnings leaves the countries in which they operate in the form of dividend payments rather than being reinvested.

The last chapter of this section is "The unique development of non-financial corporations in Latin America" by Noemi Levy-Orlik and Jorge Alonso Bustamante-Torres, in which the authors discuss the impact of foreign flows on non-financial corporations, followed by a revision of FDI trends in term of volume and composition, looking at their impact on industrial development and its links with domestic financial markets. They also revise the development of Latin American non-financial corporations and argue that their overcapitalisation process differs from multinational corporations based in developed economies, for which they provide a detailed analysis of financial indicators of balance sheet and income statement from Chile, Brazil and Mexico.

The second section of this volume focuses on "Non-financial corporations and economic growth" and contains four chapters. The first is "Capital flows, the role of non-financial corporations and their macroeconomic implications: an analysis of the case of Chile". Esteban Pérez-Caldentey and Nicole Favreau-Negront argue that the behaviour of the balance-of-payments, specifically the capital/financial account in Chile, is explained by financial and not real factors, reflecting the interactions of specific sectors. Particularly the rising importance of the international bond market is used by a minority of firms to issue debt in the international capital markets to counteract their falling profits. Thereby the international bond market is not a source of finance of real activity, turning into a space in which these firms can guarantee their financial survival.

In Chapter 8, entitled "Foreign direct investment in the Mexican steel industry", Samuel Ortiz-Velásquez discusses foreign investment determinants in the Mexican steel industry, specifically three foreign subsidiaries: Tenaris-Tamsa, Gerdau-Corsa and Novametal-TIM corporations. The working hypothesis of this chapter is that investment is explained by microeconomic and institutional variables rather than macroeconomic determinants.

In the following chapter, Ximena Echenique-Romero discusses the "Excess international liquidity and corporate financing in Mexico: reflections from USA monetary policy of quantitative easing" in the light of three objectives. First, the relation of the USA quantitative easing policy and the structure of corporate refinancing in Mexico; second, the effects of the US international liquidity international interest rate differentials, the efficiency of international financial markets, and prices of financial assets; and finally, the connection of Mexican 
corporate financing and the stock market, highlighting that shares are the principal financing mechanism.

The last chapter of this section, written by Marcelo Varela-Enríquez and Gustavo Adrián Salazar discusses "Foreign direct investment in Latin America: effects on growth and development, 1996-2017". These authors examine the effectiveness of foreign direct investment on economic growth and development in Latin America between 1996 and 2017. They conclude that direct foreign investment contributes positively to economic growth measured by variations in GDP, while money flows captured from the balance of net income balance of payments and sent abroad negatively affect human development.

The final section of this book deals with "Capital movement and economic patterns" and contains four chapters. In Chapter 11, focusing on "Latin American international integration and global value chains: what changed after the 2008 global financial crisis", Juan Pablo Painceira and Alexis Saludjian discuss the development strategies of industrial countries (United States and the European Union) and developing economies (Latin America, particularly Brazil) after the GFC. According to the authors, the main international strategies of developed countries moved towards protectionism (USA and EU), while developing economies continued to support trade liberalism, reversing the strategies of international integration between countries of the centre and the periphery, affecting multinational companies' strategies, particularly China's role in the world economy and modifying finance issues.

In the following chapter, "From 'downpour of investments' to debt crisis: the case of Argentina 2015-2019", Cecilia Allami, Pablo Bortz and Alan Cibils argue that in Argentina, in the period of President Macri (2015 and 2019), a radically different macroeconomic policy plan was imposed. Against the expectations in this new period, deregulation and financial liberalisation neither creates a "rain of investment" nor equilibrated the structural external imbalances or achieved economic growth. Instead, a substantial increase in external portfolio investment took place, whose objective was short-term returns guaranteed by monetary policy and the Argentinian government was obliged to apply for rescue plans. which came along with the traditional stabilisation and adjustment packages.

In Chapter 13, Gonzalo Cómbita-Mora and Álvaro Martín Moreno-Rivas write on the issue of "The hegemony of big corporations and internationalization of capital: a stagnation model with restricted democracy". These authors state that the dynamics of Colombia's economy has favoured the consolidation of a productive structure that benefits large corporations. This chapter's hypothesis is that mining, energy sectors (dominated by multinational corporations) and national corporations in the agro-industrial sectors required the displacement of the Afro-descendant Indians and peasants from Colombian territories, aggravating the armed conflict and the combat against drug trafficking. To validate this argument, the authors construct a novel theoretical and empirical framework that considers economic analyses and political aspects that endanger the globalisation process.

In the final chapter, "Extractive capitalism: transnational miners and Andean peasants in Peru", Alejandro Garay-Huamán analyses the socio-economic impact of transnational extractive capital in the Andean communities of northern Peru, and the traditional socio-economic transformations within the limits of the development-underdevelopment duality. The relations between the capitalist and non-capitalist sectors are discussed in the light of dependency theory, production organisation and imperialism. On this basis, the author develops an alternative framework that accounts for the relation between transnational capital and the 
non-capitalist (peasant) sector connected through global chains of production, following the Marxist concept of class. Special emphasis is given to the production process, distribution, and the appropriation of surpluses, including extra-economic processes, required for the existence of these surpluses. All these concepts allow for an analysis of complex relationships between transnational corporations, the financial sector, the extractive sector workers, and peasants, within global production chains of gold, silver and copper.

\section{NOTE}

1. Kaltenbrunner and Painceira (2017) argue that financial globalisation introduced a new asymmetry between currencies of developed and developing countries, since it was a new mechanism of profit shifting for developed countries.

\section{REFERENCES}

Aguiar de Medeiros, C. and Trebat, N. (2018). Las finanzas, el comercio y la distribución del ingreso en las cadenas globales de valor: implicancias para las economías en desarrollo y América Latina. In Perez. Caldentey E. and Valdecantos S. (eds), Estudios sobre financierización en América Latina, ABELES (171-204). Chile: Cepal.

Bellofiore, R., Garibaldo, F. and Halevi, J. (2010). The global crisis and the crisis of European neomercantilism. Socialist Register, 47(1), 121-146.

Borio, C. and Disyatat, P. (2015). Capital flows and the current account. Taking financing (more) seriously. BIS, Working Paper 525, October.

Dowrick, S. and Rogers, M. (2002). Classical and technological convergence: beyond the Solow-Swan growth model. Oxford Economic Papers, 54(3, July), 369-385.

Kalecki, M. (1971). Selected Essays on the Dynamics of the Capitalist Economy, 1933-1970. Cambridge: Cambridge University Press.

Kaltenbrunner, A. and Painceira J. P. (2017). Subordinated financial integration and financialization in emerging capitalist economies: the Brazilian experience. New Political Economy, 23(3). doi: 10.1080/13563467.2017.1349089.

Lazonick, W. and O'Sullivan, M. (2000). Maximizing shareholder value: a new ideology for corporate governance. Economy and Society, 29(1), 13-35.

McKinnon, R. (1973). Money and Capital in Economic Development. Washington, DC: The Brookings Institution.

Solow, R. M. (1963). Capital Theory and the Rate of Return. Amsterdam: North-Holland.

Steindl, J. (1952). Maturity and Stagnation in American Capitalism. New York: Monthly Review.

UNCTAD (n.d.). The top 100 non-financial MNES from developing and transition economies, ranked by foreign assets, different years. UNCTAD/Erasmus University data. Retrieved from https://unctad.org/ Sections/dite_dir/docs/wir2005top100_en.pdf, accessed 20 March 2020. 